Neuro Images
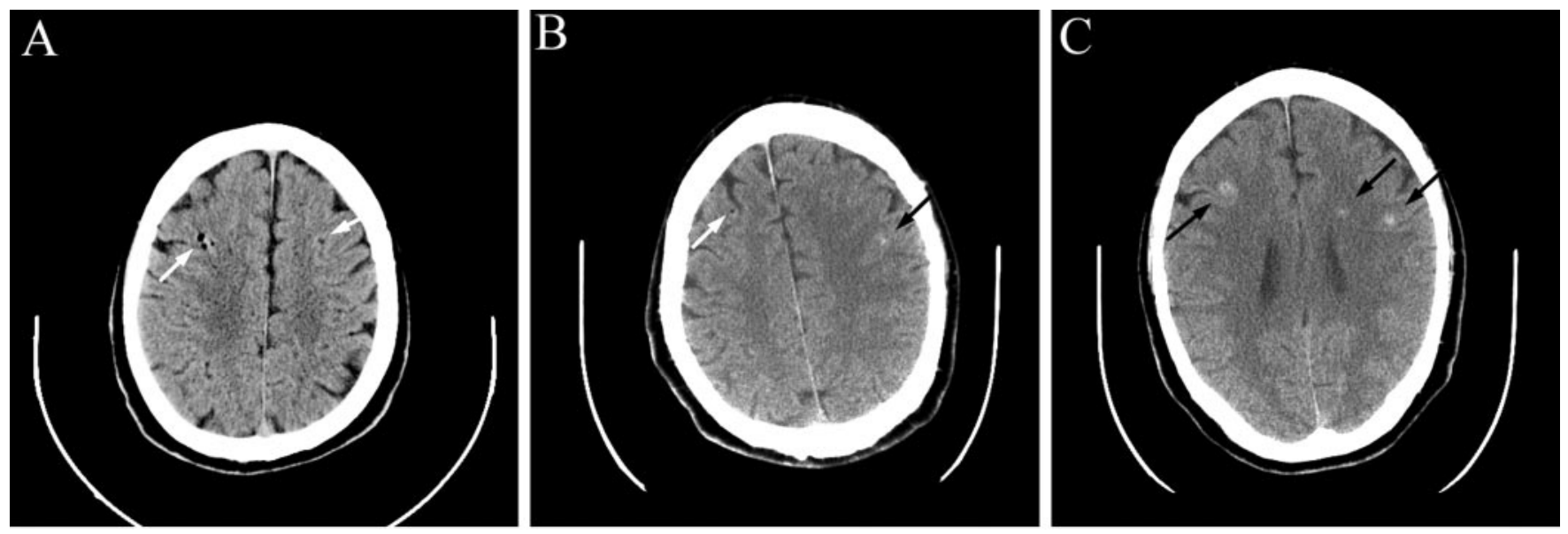

Figure. Axial CT imaging of brain shortly post-event (A) shows multiple punctate, hypodense foci (air bubbles) at the gray/white junction bilaterally (white arrows); 20 hours post-event (B) shows resolution of most hypodensities, but residual hyperdensities likely representing hemorrhage (black arrow); 5 days post-event $(C)$, only small hyperdensities remain.

\section{Cerebral air embolism during transbronchial biopsy}

Stephen M. Maricich, PhD, MD, Ronald A. Rauch, MD, Perry J. Foreman, PhD, MD, Houston, TX

A 55-year-old man with a history of prior rectal carcinoma underwent elective bronchoscopy and transbronchial biopsy for evaluation of a new lung mass. At the precise point of biopsy, he

Address correspondence and reprint requests to Dr. Stephen M. Maricich, Department of Child Neurology, Texas Children's Hospital, Baylor College of Medicine, 6621 Fannin St. CC 1710 Houston, TX 77030; e-mail: maricich@bcm.tmc.edu had a short tonic-clonic seizure followed by irritability, disorientation, and hemiparesis of his left face, arm, and leg. The timing of the event and appearance on CT (figure) suggested the diagnosis of cerebral air embolism (CAE). Although rare, CAE can be a potentially life-threatening complication of this procedure..$^{1,2}$ Our patient returned to his normal neurologic baseline within 48 hours of the event without intervention.

1. Erickson A, Irwin RS, Teplitz C, Corrao WM, Tarpey JT. Cerebral air embolism complicating transbronchial biopsy. Ann Intern Med 1979;90: 937-938.

2. Wherrett C, Mehran RJ, Beaulieu M-A. Cerebral arterial gas embolism following diagnostic bronchoscopy: delayed treatment with hyperbaric oxygen. Can J Anesthesiol 2002;49:96-99. 


\section{Neurology}

\section{Cerebral air embolism during transbronchial biopsy}

Stephen M. Maricich, Ronald A. Rauch and Perry J. Foreman

Neurology 2004;62;1438

DOI 10.1212/01.WNL.0000118289.37967.0B

\section{This information is current as of April 26, 2004}

\section{Updated Information \&} Services

References

Permissions \& Licensing

Reprints including high resolution figures, can be found at: http://n.neurology.org/content/62/8/1438.full

This article cites 2 articles, 0 of which you can access for free at: http://n.neurology.org/content/62/8/1438.full\#ref-list-1

Information about reproducing this article in parts (figures,tables) or in its entirety can be found online at:

http://www.neurology.org/about/about_the_journal\#permissions

Information about ordering reprints can be found online: http://n.neurology.org/subscribers/advertise

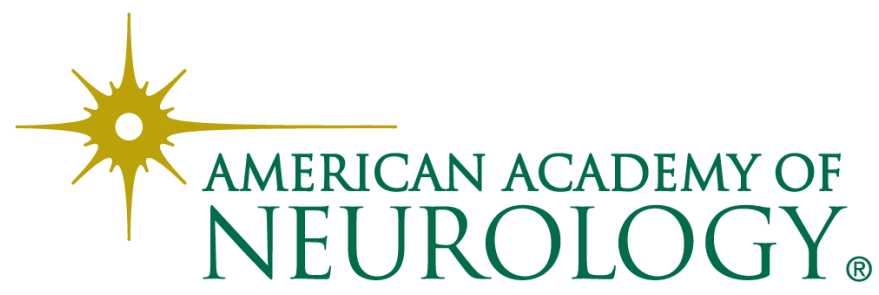

